\title{
Into Thinner Air: The Pliocene Demise of the Giant Volant Birds
}

\author{
Alan Cannell ${ }^{1}$
}

1 Istituto Italiano Di Paleontologia Umana; alcannell@gmail.com

\begin{abstract}
Simple Summary: All very large flying birds with a mass greater than $20 \mathrm{~kg}$ became extinct about 3 million years ago. One possible reason for this is bio-mechanical stress during takeoff in less dense air. This possibility is examined using a bird flight simulation model and a paleo-air density value derived from two different proxies. Takeoff airspeed and power requirements for the three known species at this value are found to be similar to those of large extant birds, but at present air density, takeoff speed is significantly higher. The escape of lighter isotopes of nitrogen during long periods of weak geomagnetic fields could be a possible explanation for this loss in atmospheric mass and how this would appear in the geological record and how it would affect the climate in terms of cooling is discussed.
\end{abstract}

\begin{abstract}
Three genera of very large volant birds existed for most of the Pliocene: the Pelagornithidae seabirds; the large North American Teratornithidae and the stork Leptoptilos falconeri in Africa and Asia. All became extinct around $3 \mathrm{Ma}$. The reasons for their demise are puzzling, as the Pelagornithidae had a world-wide evolutionary history of more than $50 \mathrm{Ma}$, smaller teratorns were still extant in the Holocene and smaller stork species are still globally extant. Extant large birds have a common critical takeoff airspeed suggesting a biomechanical limit in terms of power, risk and launch speed, and simulations of the flight of these extinct species suggest that at 1 bar they would have exceeded this value. Estimates for the Late Pliocene atmospheric density are derived from marine and terrestrial isotopes as well as resin chemistry, both approaches suggesting a value of about 1.2 bar, which drops to present levels during the period 3.3 to 2.6 Ma, thus a loss in atmospheric density may have caused biomechanical and ecological stress contributing to their extinction and/or development of smaller forms. This hypothesis is examined in terms of a possible mechanism of atmospheric mass loss and how this would be seen in the geological record. At 1.2 bar all the extinct species present takeoff airspeeds similar to large extant volant birds and which match the expected power and kinetic energy levels.
\end{abstract}

Keywords: Pelagornithidae; Teratornithidae; takeoff airspeed; paleo-air density; extinction

\section{Introduction}

The Eocene to Miocene periods witnessed the emergence of the largest volant birds, in particular the $70 \mathrm{~kg}$ teratorn, Argentavis magnificens, the Giant Pelagornithidae (toothed beak) seabirds and the giant stork Ephippiorhynchus tchoufour. The mass of Argentavis, based on the large size of these fossils and their relationship to other teratorns, was estimated at $72 \mathrm{~kg}$ by Campbell \& Marcus (1992) [1] and $64.5 \mathrm{~kg}$ for the smaller Valle de Santa Maria specimen (Campbell, 1995)[2], $78 \mathrm{~kg}$ and $80 \mathrm{~kg}$ based on the tibiotarsus as tested against teratorn and condor data (Palmqvist \& Vizcaíno, 2003)[3]. The largest known toothed beak specimen, $P$. sandersi from the late Oligocene (25-28 Ma), was found in South Carolina (Ksepka, 2014)[4] and a more complete, but slightly smaller specimen (P. chilensis), was found in the Atacama region of Chile in deposits that date to the Tortonian-Messinian Miocene (about 7 Ma) (Mayr \& Rubilar-Rogers, 2010; Cenizo et al., 2016). Kloess et al (2020) [5-7], indicate that Giant forms existed about $50 \mathrm{Ma}$, a nearly complete pelagornithid humerus (SGO.PV 22001) recovered in 2011 being larger than P. chilensis. 
Mass estimates based on femur and tibiotarsus circumferences range from 21.9 to $40.1 \mathrm{~kg}$ for P. sandersi (Ksepka 2014)[4] and from 15.6 to $28.6 \mathrm{~kg}$ for P. chilensis (Mayr \& Rubilar-Rogers, 2010)[5]. However, Field et al. (2013)[8] have shown that methods of estimating the mass of fossil volant birds in species with relatively short legs do not correlate as well as other dimensions, such as maximum coracoid lateral length, which when applied to the specimen MNHN SGO.PV 1061 (Mayr \& Rubilar-Rogers 2010)[5] gave a value of over $40 \mathrm{~kg}$ (Cannell 2020)[9]. The linear dimensions of the tarsometatarsus of Ephippiorhynchus tchoufour (saddlebill stork), were about 50\% larger than extant species and may have stood at up to $2.20 \mathrm{~m}$ in height. (Louchart et al 2008)[10]. Based on extant species (Elliott et al 2020)[11] this implies a wingspan of $4 \mathrm{~m}$ and mass of up to $25 \mathrm{~kg}$ for a male; or with a full crop, a takeoff mass of about $28 \mathrm{~kg}$.

These three giant bird orders were still represented in the Late Pliocene and the last known specimens were: the teratorns, T. incredibelis with an estimated mass of $25 \mathrm{~kg}$; the pelagornithid, P. mauretanicus with a mass of about $24 \mathrm{~kg}$ and the stork, Leptoptilos falconeri with a mass of around $20 \mathrm{~kg}$. However, all these species became extinct at the end of the Pliocene for reasons that are not understood. A change in air density may have affected their flight bio-mechanics and this hypothesis is investigated using simulations with the Flight 1.25 program (Pennycuick 2008)[12], which allow flapping cruising speeds and takeoff stall airspeeds to be estimated at different air densities and compared with the maximum takeoff airspeeds of extant large birds. The results are examined in terms of the Pliocene climatic conditions and estimates of paleo atmospheric mass (considered as paleo-Patm in bar) derived from two independent proxies: $\mathrm{pCO}_{2}$ as derived from marine boron isotopes and terrestrial sources, and the property of amber (resin) to preserve the biochemistry of the atmosphere when it was produced.

Atmosphere can be lost due to impacts, massive erosion and the preferential loss of lighter isotopes in solar wind events (Xiang et al 2016)[13]. The latter may be of particular importance during periods with weak geomagnetic fields (Wei et al 2014, Schillings et al (2019), Wong et al 2013)[14-16]. Measurements from bubbles trapped in ice cores, for example, have shown that $\mathrm{pO}_{2}$ has dropped over the past 800 ka (Stolper et al 2016)[17], which also implies that $\mathrm{pN}_{2}$ has increased; although it is not possible to establish which gas has kept the most stable atmospheric mass. Rimmer et al (2019) [18] conclude that in view of the variable nature of atmospheric nitrogen it could also be expected that Patm has both increased and decreased many times in the geological past. As stated by Johnson \& Goldblatt (2018)[19]: the assumption that atmospheric mass should be constant over Earth's history is not an inherent property of the planet.

The last geomagnetic multiple reversal events (in particular the Mammoth and Kaena Reversals) took place at the end of the Pliocene and timing of the low magnetic intensity of this period is compared to the paleo-Patm proxies, the extinction of the large birds and climatic effects. The hypothesis presented is that the very large birds possibly flourished in an environment with a higher air density, part of which may have been lost during periods of low geomagnetic intensity leading to bio-mechanical and ecological stress. The larger species then became extinct and either new species of smaller birds evolved that were adapted to modern atmospheric densities, or the bird clade became extinct. 


\section{Last Known Specimens of the Giant Birds of the Pliocene}

\subsection{Teratornithidae}

The giant teratorn, Argentavis magnificens is only known from Argentinian fossils from the Miocene. Smaller teratorns such as teratornis merriami, with an estimated wingspan of 3.2 and mass of about $14 \mathrm{~kg}$ became extinct at the end of Pleistocene. A large teratorn (T. incredibelis) was found in late Pliocene deposits in California, linear dimensions suggesting it was about $30 \%$ smaller than argentavis and $30 \%$ larger than merriami. A premaxillary was also found from the late Pliocene ( 3.5 to $3.2 \mathrm{Ma}$ ), a partial proximal shaft was dated to 1.8 to $0.9 \mathrm{Ma}$, but is severely crushed and thus difficult to scale, however, it differs from known teratorns and is slightly larger. A large fragment of a right carpometacarpus from Florida was dated at between 1.66 and $1.4 \mathrm{Ma}$, but in the same deposits were found fossils of an early and smaller T merriami (Campbell \& Tonni 1983)[20]. Campbell et al (1999) [21] conclude that the carpometacarpi cannot be used for scaling due to poor preservation; nevertheless, a reasonable estimate for the size of T. incredibelis would be of a bird of a size between $A$ magnificens and T merriami.

Based on a $30 \%$ linear increase of $T$ merriami and the relationship between wing area and mass for raptors (Cannell 2020) [9], its wingspan would be about $4.2 \mathrm{~m}$, with Aspect Ratio (AR) of around 8.5 and mass of about $25 \mathrm{~kg}$. Flight muscle mass in teratorns may have been higher than the usual bird standard of $17 \%$ adopted in Flight 1.25 and a value of 19\% was adopted, as discussed in Cannell (2020)[9].

\subsection{Pelagornithidae}

Fragments of a pelagornithid classed as P. mauretanicus from Ahl al Oughlam, Casablanca, Morocco were dated 2.5 Ma (Mourer-Chauviré and Geraads, 2008)[22]. At the time of deposition, the site consisted of a network of fissures and interconnected galleries in a jumble of calcarenite blocks at the foot of what was then a cliff on the shore (Louchart et al 2013)[23]. This dating was based on the faunal assemblage and the possibility thus exists that these deposits are secondary and some of the creatures may have flourished at an earlier or later dates. This is noted by Mourer-Chauviré and Geraads (2010) [24], as the marine avifauna shows many similarities with that of the older Yorktown Formation in North Carolina, dated to 4.5 to $5 \mathrm{Ma}$, however, the authors state that pseudodontorns were present in North America, New Zealand, Japan, and Peru during the Pliocene, the Ahl al Oughlam form, dated from $2.5 \mathrm{Ma}$, is the most recent form known to date.

Discovery of a proximal Pelagornis humerus (UCMP 219007; University of California Museum of Paleontology, Berkeley, California, U.S.A.) from the Middle-Upper Pliocene ( 3.35-2.5 Ma) Purisima Formation of northern California represents the youngest record of Pelagornithidae from the Pacific Ocean basin and demonstrates that pelagornithids survived in both the Atlantic and Pacific Oceans until the late Pliocene. This fossil from Santo Gregorio Beach California, is a proximal portion of a left humerus with a long, dorsoventrally-compressed shaft, measuring $385 \mathrm{~mm}$. A prominent protuberance occurs near the ventral margin of the anterior surface of the shaft ventral to the deltopectoral crest, 113 $\mathrm{mm}$ from the proximal end. Compared with the biostratigraphically dated Pelagornis mauretanicus from Morocco, the more precise dating makes it the youngest reliably dated pelagornithid fossil worldwide with an estimated age of between 3.35-2.6 Ma (Boessenecker and Smith 2011) [25]. This upper limit of 2.6 Ma (late Pliocene tephra) is much younger than expected from lithologic correlations that assign these strata to the late Miocene Tahana Member, however, the age of this tephra cannot be older than about 3.3 Ma, the age of the disseminated ash horizon found stratigraphically lower in the Purisima Formation and to the south (Powell et al 2007)[26].

The latest dates for pelagornithids are: Peru - about 3 to 3.9 Ma (Chavéz et al. 2007) [27], Japan and New Zealand - 3.1 to 3.6 Ma (Ono 1989) [28], California - 2.6 to 3.4 Ma and Morocco $-2.5 \mathrm{Ma}$ (with the reservations covered above). Thus around $3 \mathrm{Ma}$ these birds, an avian clade with a temporal span of more than 55 million years and a worldwide geo- 
graphic distribution became extinct. Boessenecker and Smith (2011)[25], among many others, find it puzzling that such a long-lived, cosmopolitan, and presumably adaptable taxon such as the Pelagornithidae did not survive whereas many other sea birds continued to thrive.

The wingspan of this specimen was estimated by Boessenecker and Smith [25] at between 4.3 to $5.37 \mathrm{~m}$, slightly smaller than the Miocene P chilensis, yet still one of the largest volant birds ever reported. The "teeth" spacing from Ahl al Oughlam fossil, although similar to $P$ chilensis, is about $85 \%$ smaller, suggesting a wingspan of about $5.5 \mathrm{~m}$ (based on simple linear beak dimensions) with AR of 18 (Campbell \& Tonni, 1983, Cannell 2020)[20,9]. If the $P$ chilensis had a mass of up to $40 \mathrm{~kg}$ these recent specimens would possibly have been about 20 to $24 \mathrm{~kg}$ (full crop) and wingspan of $\sim 5.1 \mathrm{~m}$ (average of the three estimates).

\subsection{Ciconiidae (Leptoptilini)}

The very large extinct species of stork, Leptoptilos falconeri, was represented during the Pliocene in the Northern half of Africa, South Asia (Siwalik Hills, India, late Pliocene) and probably also in the Ukraine. In the latest Pliocene fossils have been found in Omo, Ethiopia and Koro Toro, Chad (Louchart et al 2005) [29]. According to Louchart et al (2005) [29], the diversity of the Leptoptilini has been overestimated, and L. falconeri appears to remain the only valid extinct species of this tribe in the Pliocene.

L. falconeri weighed about $20 \mathrm{~kg}$ and probably stood up to $2 \mathrm{~m}$ tall and had relatively slightly reduced forelimbs, allometrically congruent with a slight limitation in flight abilities for a bird of large size and mainly terrestrial habits; it became extinct by the end of the Pliocene and the reasons for its extinction remain enigmatic (Louchart et al 2005) [29]. These dimensions suggest a linear scaling increase over the extant Marabou stork (Leptoptilos crumenifer) of about $33 \%$, giving a wingspan of $3.72 \mathrm{~m}$, or with the slightly reduced forelimbs, around $3.6 \mathrm{~m}$ - as compared to the value of $2.8 \mathrm{~m}$ for a $9 \mathrm{~kg}$ extant Marabou stork. Aspect Ratio (AR) would thus be slightly less than extant large storks, at about 9 .

\section{Materials and Methods}

To test the effect of any change in the density of the flight medium, simulations were carried out with the widely used flapping model Flight 1.25 (Pennycuick 2008)[12]. The input data used the above mass, wingspan and wing shape (AR) values. Flight muscle percentage was the program standard of $17 \%$, except for the teratorns simulations, which adopted a slightly higher value of $19 \%$. The output of these simulations gives cruising airspeed at minimum power; climb rate at maximum power and myofibril work. Takeoff airspeed is taken as $70 \%$ of level cruising speed at minimum power based on ultra-light aircraft designs and which agree with the running and flapping takeoff speeds of large extant birds (Cannell 2020)[9].

A problem of bird flight aerodynamic models (such as Flight 1.25) is that when applied to flight with an acceleration component (for example, takeoff) their predictions are at best an indication of relative power values (Nudds \& Bryant 2002) [30]. However, many birds start takeoff from an initial jump, and a frame by frame analysis of multiple videos of storks taking flight shows that they follow the pattern described in the literature of rapid leg extension, together with a strong wing upstroke to gain both forward and upward acceleration (Askew et al 2001, Earls 2000, Provini et al 2014)[31-33].

Borelli, in De Motu Animalium (1680) suggested that vertical takeoff speed should be the same regardless of animal size (Bobbert 2013)[34], and this "Borelli's Rule" was confirmed by Newton who reasoned that to jump to a given height (h) in a gravitational filed (g), an animal must achieve a vertical takeoff velocity (v), which corresponds to kinetic energy, such that:

$\mathrm{h}=\mathrm{v}^{2} / 2 \mathrm{~g}$, and is independent of mass. 
Bobbert (2013)[34] found that size does affect jump height, but the vertical velocities reached were remarkably constant over a wide range of linear scaling. Thus, although for the critical takeoff phase of the teratorns and pelagornithid a flapping and running simulation approach can be used, for the stork a different method is adopted based on the kinetic energy needed to reach minimum airspeed.

To determine the air densities - or paleo air pressure - to be tested, two independent proxies were adopted: resin/amber and the difference between marine and terrestrial derived $\mathrm{pCO}_{2}$.

\subsection{Resin/Amber 113C isotope}

Amber occurs worldwide as 'bursts' in the geological record: the early Late Triassic (Carnian, 237-228.4 Mya), the Early to mid-Cretaceous (145-96 Mya), the Eocene (56-33.94 Mya) and the late Oligocene to the Miocene (28-5.8 Mya) (Seyfullah 2018)[35]. Warm, humid and higher air density conditions favour photosynthesis (Takeishi et al 2013)[36] and thus resin production and general biodiversity. It is noteworthy that these periods also coincide with the development of flight: pterosaurs (Kellner 2015)[37] and 'flying fish' (Xu et al 2013)[38] in the Mid to Late Triassic; the well-known emergence of gliding mammals, birds and several unusual gliding or flying therapods in the Late Jurassic - Early Cretaceous; birds and the iconic large pterosaurs in the Cretaceous; Giant Pelagornithids (Cenizo et al 2015)[6], the Bat 'Big Bang' (Simmons 2005) [40] in the Eocene; and the Giant Birds of the Miocene [9].

Tappert et al (2013)[41] note that resins have chemical properties that have not changed significantly with plant evolution and that make them particularly suitable as proxies of environmental changes over geological time. For copious resin producers it was therefore assumed that the metabolized $\mathrm{CO}_{2}$ was sourced from isotopically undisturbed air that had a $\delta 13 \mathrm{C}$ composition approximating a global atmospheric average. The authors also remark that several definite trends appear in the data, yet the known observation that $13 \mathrm{C}$ fractionation in plants increases with increasing $\mathrm{pCO}_{2}$ cannot account for the $\delta 13 \mathrm{C}$ shifts in the resin record and therefore some other process must be responsible. Diagenesis is dismissed as, if this were the case, fossil resins from different localities should show an erratic distribution of the $\delta 13 \mathrm{C}$ resin mean, which is not observed in the data nor considered in the chemistry of amber by Nissenbaum \&Yakir (1995)[42]. Insect attack has been shown to affect resin composition by enriching $\delta 13$ C levels (McKellar et al 2011)[43], but leaving the resin turbid; clear samples should thus be less affected.

Similar data for the Miocene was found by Kocsis et al (2019)[44\} in the amber from Brunei, in which modern resin yielded on an average 3\% lower $\delta 13 \mathrm{C}$ values, with a decreasing trend in average $\delta 13 \mathrm{C}$ of about $1 \%$ from the late middle Miocene to late Miocene. The authors mention that this could be explained by gradual changes in local environmental conditions or an increased amount of less mature specimens among the younger samples; however, Tappert et al (2013)[41] found this same trend in Mexican, Dominican and Malaysian samples, suggesting a more global explanation.

An evaluation of the effect of a variable $\mathrm{pO}_{2}$ on amber isotopes, using experimental work on the isotopic fractionation in C3 plants and partial pressure of oxygen, revealed that the fractionation of carbon during photosynthesis was found to increase when the $\mathrm{pO}_{2}$ in the ambient air is significantly higher than modern values, resulting in depleted 13C plant mass (Berner et al 2000) [45]. The opposite effect has also been observed under lower than modern $\mathrm{pO}_{2}$ in ambient air (Beerling et al 2002)[46]. From these observations, Tappert et al (2013)[41] considered that a direct relationship is a reasonable assumption for moderate $\mathrm{pO}_{2}$ levels, provided that major physiological adaptations of plants are not involved.

In this empirical model, paleo- $\mathrm{pO}_{2}$ at the time of resin formation may have been as low as $13 \%$ in the Eocene and $18 \%$ in the Mid-Miocene. This is starkly at variance with all versions of the standard Geocarbsulf and Geoacarbsulfor models and fire activity in pure sphagnum moss peat - a highly flammable and easily ignitable material that burns in 
modern natural fires - is effectively "switched off" at $\mathrm{pO}_{2}<16 \%$ (Belcher et al 2010)[47]. Possibly for these anomalies in relation to established geological models and wildfires, this link of resin chemistry to paleo $\mathrm{pO}_{2}$ has not received the attention it deserves.

The possibility that the Patm of these periods may have been higher, however, has yet to be considered. At higher pressure, low levels of $\mathrm{pO}_{2}$ not only sustain biological processes, but are essential to avoid oxygen poisoning. A modern example of this is deep sea diving: in order to work at $130 \mathrm{~m}$ depth in the northern sector of the North Sea oil field, for example, the breathing mixture used only contains $10 \%$ oxygen (Wilmshurst 1998) [48].

Thus the mass estimates of $\mathrm{O}_{2}$ based on the Geocarbsulf model data (Berner 2006; Royner et al 2014) [49-50] and on the $\mathrm{pO}_{2}$ derived from resin/amber data can be reconciled by varying the Patm values (air density) of the resin model such that the $\mathrm{mol} \mathrm{m}^{-3}$ are similar, essentially by increasing the atmospheric mass by the relevant factor:

\section{Paleo Patm $=\left(\mathrm{pO}_{2} \mathrm{gcs} / \mathrm{pO}_{2} \mathrm{amb}\right)$ bar}

where $\mathrm{pO}_{2}$ gcs is the values estimated from the geocarbsulf model and $\mathrm{pO}_{2}$ amb is from amber data. Carbon isotope data from more recent "Borneo Amber" (Kocsis et al 2020) [44] suggests that, unlike the gradual change in $\mathrm{pO}_{2}$ from Tappert et al (2013) [41] from the Miocene to the present, $\mathrm{d} 13 \mathrm{C}$ levels remain enriched up to around $3 \mathrm{Ma}$. As there is no evidence that $\mathrm{pO}_{2}$ has radically changed since the Miocene, the derived $\mathrm{pO}_{2}$ value for the Late Pliocene would be slightly less than $18 \%$, which to reach the Geocarbsulf model value of $21 \%$, would require an increase in Patm of around 1.2 bar, the Borneo amber isotope data suggesting that any loss in Patm would have been about 3 Ma.

\subsection{Marine and Terrestrial Derived $p \mathrm{CO}_{2}$}

The ability of boron isotopes in foraminifera to record seawater $\mathrm{pH}$ stems from the acid-base equilibrium between boric acid and borate ion. Marine carbonates have boron isotopic compositions of $15-25 \%$, substantially lower than that of seawater $(39.61 \%$ ). This is due to the dominant incorporation of borate ion into growing carbonate, so as the boron isotopic composition of borate varies with $\mathrm{pH}$, so does $\delta 11 \mathrm{~B}$ of marine carbonate (Rae et al 2001, 2018) [51-52]. The main interest in this technology stems from the ability to reconstruct past $\mathrm{CO}_{2}$ from paleo- $\mathrm{pH}$, as these are closely coupled in seawater, both being governed by the primary carbonate system variables. rom knowledge of aqueous [ $\left.\mathrm{CO}_{2}\right]$, along with estimates of temperature and salinity, Henry's Law allows calculation to be made of the partial pressure of atmospheric $\mathrm{CO}_{2} 2$ in equilibrium with this water.

Curiously, the $\mathrm{pCO}_{2}$ values derived from marine (benthic) carbonates are higher than the values derived from stomata or $\mathrm{C} 3$ data and this difference in sea water derived $\mathrm{CO}_{2}$ and terrestrial based data has long been something of a paradox and similar to the "enigmatic" conditions of the Oligocene ( $\mathrm{O}$ 'Brien et al 2020)[53]. However, a possibly overlooked factor in this process is air pressure. The oceans absorbs a large amount of $\mathrm{CO}_{2}$ due to the relatively high solubility of this gas in seawater, with the dissolved $\mathrm{CO}_{2}$ participating in chemical and biological processes while being circulated around the global ocean; this results in generally negative partial pressure $\left(\mathrm{pCO}_{2}\right)$ gradients at the air-sea interface which drive $\mathrm{CO}_{2}$ uptake by the ocean. The solubility of $\mathrm{CO}_{2}$ in seawater is often measured as the Henry's Law Constant $(\mathrm{KH})$ and expressed as [ $\left.\mathrm{mol}\left(\mathrm{kg} \mathrm{H}_{2} \mathrm{O}\right)-1 \mathrm{~atm}-1\right]$; this varies with temperature, but is approximately linear over the range $0 \mathrm{C}$ to $50 \mathrm{C}$ and directly proportional to partial pressure (Bailey et al 2018)[54]. What is often ignored, however, is that $\mathrm{KH}$ is also expressed in terms of [atm], as the solubility $\mathrm{CO}_{2}$ is highly responsive to air pressure - about 55 times greater than that of $\mathrm{N}_{2}$ at $20 \mathrm{C}$. Although this can be seen almost on a daily basis when opening a can of soda ( 1.25 bar at $20 \mathrm{C})$, surprisingly few studies on this property have been carried out.

Al-Anezi et al (2008)[55] examined the solubility of $\mathrm{CO}_{2}$ in a solution of 35,000 ppm $\mathrm{NaCl}+\mathrm{MgCl} 2+\mathrm{Na} 2 \mathrm{SO} 4$ (similar to real seawater) at 1 and 2 bar and over several constant temperatures. At $25 \mathrm{C}$ and 1 bar the solubility was $70\left(\mathrm{CO}_{2}\right.$ concentration in ppm), at 2 bar 
it rose to 550 ppm (their figures 6 and 7, note that Fig. 6 appears to have squares and diamonds inverted). Assuming a linear difference - reasonable as $\mathrm{CO}_{2}$ solubility in water from 0.1 bar to 0.9 bar is almost linear (their figure 18) - this gives a gradient of about 48 ppm per 0.1 bar. Thus for derived values from marine and terrestrial sources:

\section{Marine $\mathrm{pCO}_{2}=$ Terrestrial $\mathrm{pCO}_{2}+$ Component from any Difference in Patm}

Marine derived $\mathrm{pCO}_{2}$ from the mixed layer dwelling planktic species Globigerinoides ruber shows a sharp dip at the start of the Mammoth Reversal and a more permanent reduction at the start of the Kaena Reversal from about 370 ppm to 320 ppm. By the midPleistocene these are similar to pre-industrial values (de la Vega et al 2020)[56]. A similar significant drop at $3 \mathrm{Ma}$ is also shown by marine derived boron proxies (Sosidian et al, 2018; Bartoli et al., 2011; Badger et al., 2013; Martínez-Boti et al., 2015; Stap et al., 2016) [5761].

On the other hand, terrestrial based $\mathrm{pCO}_{2}$ reconstructions from stomata (Wang et al 2015, Fletcher et al 2019) [62-63] and, in particular, plant based C3 data (Cui et al 2020) [64] indicate more constant $\mathrm{pCO}_{2}$ values of below $300 \mathrm{ppm}$ for the Pliocene, Both the stomata and C3 plant data also give very consistent values in relation to other sources - including ice core and blue ice data - for the Pleistocene \{64], strongly suggesting that overall atmospheric $\mathrm{pCO}_{2}$ has been correctly assessed for the Pliocene.

Taking the marine data (average of 50 ka bins) from Martínez-Boti et al (2015) [60] and de la Vega et al (2020) [56] and comparing these values with the $\mathrm{pCO}_{2}$ derived from terrestrial C3 plants [64] and metasequoia stomata values [62], the difference between marine and terrestrial derived $\mathrm{CO}_{2}$ is seen to drop over the period from 3 to $2.65 \mathrm{Ma}$. Thus at about $3 \mathrm{Ma}$ a marine derived $\mathrm{pCO}_{2}$ of around $400 \mathrm{ppm}$ and a terrestrial derived estimate of about 260 to 290 ppm (both equivalent at 1 bar) tend to the same value after the Gauss /Matuyama reversal. To account for this difference at around $3 \mathrm{Ma}$, a possibility is that the Patm derived component would be $\left(0.1^{*} 120\right) / 48$ (from Al-Anezi et al 2008) or about 0.25 bar. Thus suggesting that sea-level air density for the warm Pliocene period was around 1.25 bar, falling to the present 1 bar in the Pleistocene.

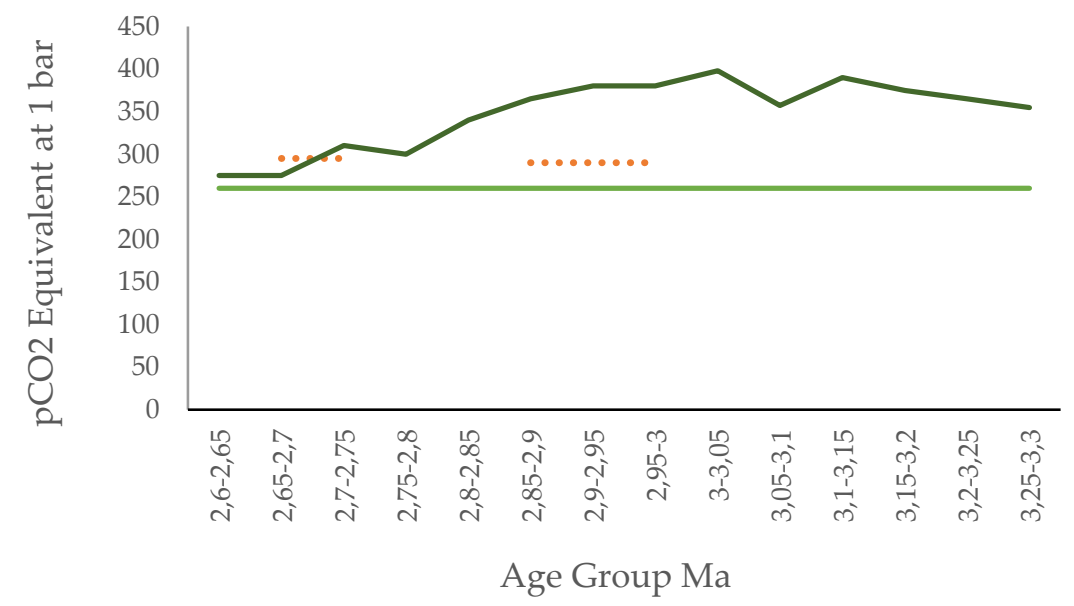

Figure 1. Marine and Terrestrial Derived pCO2 : C3 in light green (Cui et al 2020)[64], metasequoia in orange dotted (Wang et al 2015) [62] and Boron isotope in dark green, (Martínez-Botí et al (2015)[60], de la Vega et al (2020)[56], average of 50 ka bins

Thus both boron and resin proxies thus suggest a value of Late Pliocene low altitude Patm of about 1.2 bar. This value, along with the present value of air pressure of $\sim 1$ bar can be used to evaluate the flight and critical takeoff characteristics in the Flight 1.25 model. 


\section{Results}

\subsection{Teratornithidae}

At 1 bar, the Flight 1.25 cruising speed for the large teratorn is simulated at $18.8 \mathrm{~m} / \mathrm{s}$, climb rate $50 \mathrm{~cm} / \mathrm{s}$ and aerobic muscle power within the myofibril stress limits. Stall airspeed would be about $13.2 \mathrm{~m} / \mathrm{s}$ - almost $50 \mathrm{kmh}$. Even with strong and robust legs this precludes any form of 'jump' based takeoff which could only contribute to a vector of about $4 \mathrm{~m} / \mathrm{s}$ (discussed below). An option could be to run into a headwind similar to the Andean Condor (Vultur gryphus) which has a stall (takeoff) speed of about $11 \mathrm{~m} / \mathrm{s}$ at a flap rate of about $3 \mathrm{~Hz}$ (McGahan 1972) [65]. However, the experimental placement of food has shown that condors will not land in certain locations where the costs of flapping flight are extremely high (Williams et al 2020) [66].

With no headwind and on flat ground, a takeoff at over $13 \mathrm{~m} / \mathrm{s}$ could be a stressful and high risk action. As discussed below, this value is higher than the limit for all extant large birds and any change in wind could drop airspeed to below stall. At 1.2 bar the simulations show that cruise speed drops to $17.1 \mathrm{~m} / \mathrm{s}$, giving a stall estimate of $11.97 \mathrm{~m} / \mathrm{s}$ and within the extant biological limit for large birds.

\subsection{Pelagornithidae}

At 1 bar the simulation data shows that cruising speed would be $16.8 \mathrm{~m} / \mathrm{s}$ resulting in a stall speed about $11.8 \mathrm{~m} / \mathrm{s}$. Aerobic muscle power is within the limits given by Pennycuick (2008)[12] and climb a comfortable $64 \mathrm{~cm} / \mathrm{s}$ for a wingbeat of $1.69 \mathrm{~Hz}$. Swans 'run' over the water surface with wings beating in at a low angle and feet 'slapping' the water to get extra traction and support. Albatross perform a similar takeoff, whereas large pelicans use both feet to 'hop' and effectively 'row' the water surface to gain forward and upward momentum on the wing upstroke. Therefore on open water and with some form of paddle gait, getting airborne would appear to have been feasible and similar to large the takeoff of the large swan Cygnus olor, with a cruising speed of $16.1 \mathrm{~m} / \mathrm{s}$ and thus a stall of about $11.3 \mathrm{~m} / \mathrm{s}$ (Alerstam et al 2007)[67].

However, on land (necessary for nesting and chick feeding), the short legs of pelagornithidae may have been problematic: measurements of the leg bones of the Miocene $P$ chilenens (bone wingspan $4.6 \mathrm{~m}$ ) and a Wandering Albatross (Diomedea exulans) skeleton (with a bone wing span of $2 \mathrm{~m}$ ) show that the much larger and heavier Pelagornithidae had leg bones only about $20 \%$ longer than the extant albatross: Femur $(15,12.5)$; Tibiotarsus $(23,19)$ and Tarsometatarsus $(11,7.5)$ - all values in $\mathrm{cm}$ and taken from digital images: $P$ chilensis [5] and D exulans (N. Jones, Museum of Zoology, Cambridge 2016,). Gaining airspeed by running may therefore have been difficult.

At 1.2 bar, cruise speed drops to $15.3 \mathrm{~m} / \mathrm{s}$ and stall to $10.7 \mathrm{~m} / \mathrm{s}-10 \%$ less and similar to that of the wandering albatross (Pennycuick 2008) [12] for a wingbeat of $1.57 \mathrm{~Hz}$. As discussed in Cannell (2020)[9], the bone stress on the lightweight, but very long wing bones, of pelagornithids could have been critical during takeoff, and as stress is proportional to the square of the wingbeat, at 1.2 bar this reduction in frequency would be equivalent to a stress reduction of $(1.69 / 1.57)^{2}$ or $16 \%$.

\subsection{Ciconiidae (Leptoptilini)}

For the large $20 \mathrm{~kg}$ stork $L$ falconeri, the simulation setup for 1 bar (present air density) indicates that this bird with relatively shorter wings had enough power to fly at a fast cruise speed of $18.9 \mathrm{~m} / \mathrm{s}$, thus stall airspeed at 1 bar would be about $13.23 \mathrm{~m} / \mathrm{s}$. The question remains, however, on how these birds attained takeoff airspeed? Most birds start takeoff from an initial jump, and storks follow the pattern described in the literature of rapid leg extension, together with a strong wing upstroke to gain both forward and upward acceleration (Askew et al 2001, Earls et al 2000, Provini et al 2014)[31-33].

A problem of bird flight aerodynamic models (such as Flight 1.25) is that when applied to flight with an acceleration component (for example, takeoff) their predictions are 
at best an indication of relative power values and may bear little relation to reality (Nudds \& Bryant 2002)[30]. Thus for a "jump" takeoff a different approach is required that takes into account the initial jump energy, the required airspeed kinetic energy and available power. Birds jump speeds range between $1.5 \mathrm{~m} / \mathrm{s}$ for finches and doves, (Provini et al 2014)[33] to 3.25 for the Harris Hawk; 2.62 for Pigeons, to $4.81 \mathrm{~m} / \mathrm{s}$ for the Blue breasted Quail (Askew et al 2001)[31] and these values do not scale with bird size. This property was first mentioned by Borelli, in De Motu Animalium (1680), who noted that takeoff jump speed should be the same regardless of animal size (Bobbert 2013)[34]. This became known as Borelli's Rule and Newton later reasoned that to jump to a given height (h) in a gravitational filed (g), an animal must achieve a vertical takeoff velocity (v), which corresponds to kinetic energy, such that: $h=v^{2} / 2 g$ and is independent of mass. Bobbert [34] found that size does affect jump height, but the vertical velocities reached were remarkably constant over a wide range of linear scaling. Thus scaling up the linear dimension of a bird such as a stork results in the animal having a higher mass $(\mathrm{m})$, a higher stall speed (v) and needing greater energy $\left(\mathrm{m} / 2 \mathrm{v}^{2}\right)$ to reach stall airspeed, whereas initial launch (vertical jump) speed tends to be constant.

Askew et al (2001) [31] examined many species of birds (and bees) and found that over a broad range of body size $(0.0002-5 \mathrm{~kg}$ ) and contractile frequency $(5-186 \mathrm{~Hz})$, the myofibrillar power output of flight muscles during short maximal bursts is very high and of similar magnitude at $360-460 \mathrm{~W} \mathrm{kg-1}$, with the caveat that the power outputs are all short-term efforts that are not sustainable.

The largest extant storks are the Brazilian Jabirú (Jabiru mycteria) and the Marabou of Africa (Leptoptilos crumenifer), both reaching $9 \mathrm{~kg}$ (males) with wingspans of $2.8 \mathrm{~m}$ and AR of about 10 (https://museucerrado.com.br/tuiuiu). Flight 1.25 indicates a cruising flapping speed of $16.4 \mathrm{~m} / \mathrm{s}$ or a takeoff airspeed of $11.5 \mathrm{~m} / \mathrm{s}$, slightly higher than the value of 11.2 $\mathrm{m} / \mathrm{s}$ for the black stork (Alerstam et al 2007)[67]. In terms of kinetic energy, this airspeed implies a power output of $595 \mathrm{~J}$. Muscle mass (taken as $17 \%$ of total weight) is $1.53 \mathrm{~kg}$, giving a burst energy of about $612 \mathrm{~W}$. A standing launch at $3 \mathrm{~m} / \mathrm{s}$ would add about $50 \mathrm{~J}$, thus the energy acquired in one second after launch is $595-50 \mathrm{~J} / \mathrm{s}$ or $545 \mathrm{~W}$ and the ratio of burst power to energy needed is $612 / 545$ or 1.12 . The bird can takeoff.

The kinetic energy of a $20 \mathrm{~kg}$ L. falconeiri at $13.23 \mathrm{~m} / \mathrm{s}$ is $1750 \mathrm{~J}$. With a muscle mass of $3,48 \mathrm{~kg}$, burst power over one second would be $1392 \mathrm{~W}$, plus the launch velocity energy which at the same vertical rate of $3 \mathrm{~m} / \mathrm{s}$ only supplies about $90 \mathrm{~J}$. This gives a ratio of power to energy (W) of (1392/1750-90) or 0.84 for the first second of flight and thus a positive climb rate at 1 bar is not possible.

At the higher air density equivalent to 1.2 bar, stall speed drops to $12.04 \mathrm{~m} / \mathrm{s}$ thus an energy requirement of $1449 \mathrm{~J}$. Burst muscle power to energy ratio over 1 second would thus be (1392/1449-90) or 1.02. Power and energy are matched and the takeoff speed is constrained within the apparent maximum limits.

\section{Discussion}

Many factors could have either contributed to the direct extinction of these large birds or led to stress factors that reduced population sizes to unsustainable levels, such as: ecological stress, an impact event or biomechanical stress due to atmospheric loss.

\subsection{Ecological}

The marine mega fauna extinction event at the end of the Pliocene (Pimiento et al 2017) [68] is one of several studies that examine the very high levels of extinction of large marine creatures towards the end of the Pliocene, mentioning that seabirds lost $35 \%$ of their generic diversity. However, Figure 4 in their supplementary notes shows that the extinction rate for birds in the Pliocene was in fact similar to that of the other Cenozoic periods, such as the Oligocene. The authors also state that the global neritic zones area dropped from about 30 to 21 million $\mathrm{km} 2$ at the end of the Pliocene, or by 9 million $\mathrm{km} 2$. However, neritic zone area has varied even more during the Pleistocene, with sea-level 
changes of far greater amplitude during ice-age cycles and over much shorter time periods, but without major extinction events.

The assemblage of fossil birds in the coastal locality of Horcon in central Chile reveals the changes in seabird fauna in the area of influence of the Humboldt Current over the last 5 Ma and Chávez Hoffmeister et al (2014) [69] note that the Pliocene record consists exclusively of extant families. In comparison with the Late Miocene, the only suprageneric taxon absent from the Pliocene record in Chile is the Pelagornithidae, but other large birds such albatross and petrels are also rare, a possible indication that they had similar feeding habits to the Pelagornithidae. Hence the Pacific coast, at least, does not seem to have experienced a major seabird extinction event at the end of the Pliocene.

\subsection{Extraterrestrial}

The most commonly known example of an extraterrestrial extinction event is the Chicxulub KT impact, yet other events may influence life forms, such as a near supernova event. Melott et al (2019) [70] make the case for such an intense radiation period, in particular the effect of muons on the ozone layer as high energy photons and cosmic rays can ionize and dissociate molecules in the atmosphere, notably $\mathrm{N}_{2}$, resulting in a series of chemical reactions which deplete ozone and result in an increase in UVB radiation.

However, if this were the case, this radiation should affect pollen grains as has been found at the end of the Devonian (Marshall et al 2020) [71] and proposed for the end of the Permian (Benca et al 2018)[72], based on the description of malformed pollen from coeval formations over a period of about $1 \mathrm{Ma}$ (Foster and Afonin 2005)[73]. As far as can be determined, no such pollen deformations have been observed for the end of the Pliocene. It should be mentioned, though, that any process that increased UVB radiation from supernovas, lower atmospheric mass or ozone depletion due to low geomagnetic fields causes feather damage and would affect larger birds, as their primary feathers take longer to grow (Sullivan et al 2019)[74].

\subsection{Biomechanical Stress due to Atmospheric Loss}

A major reversal event, the Mammoth and Kaena transitions, took place at $3.33 \mathrm{Ma}$ ( $\mathrm{N}$ to $\mathrm{R}$ ) and at 3.01, with weak fields dominating the period (Valet et al 2020, HerreroBervera \& Valet 2005, Valet \& Fournier 2016)[75-77]. Thus the Earth's atmosphere was dangerously exposed to solar winds and solar events for tens of thousands of years. The earlier Gilbert-Gauss reversal (3.58 Ma) also resulted in a weak field before the transition, but which rapidly gained in intensity (Goguitchaichvili et al 2009, Valet et al 2020)[78, 75]

If atmospheric mass were lost (in particular the lighter isotope $14 \mathrm{~N}$ ) during a period of weakened geomagnetic field this would appear as a marked temporary rise in $15 \mathrm{~N}$ in the geological record. According to McKay et al (2012) [79] during the warmest intervals of the Pliocene from 4.5-3.0 Ma, Earth's average surface temperature was $2-3^{\circ} \mathrm{C}$ warmer than present and equator to pole temperature gradients were weaker. There was, however, a major phase of ice sheet expansion and cooling in coastal Antarctic waters at $~ 3.3$ $\mathrm{Ma}$ and, as can be seen in their Figure 1, there was a large shift in $15 \mathrm{~N}$ at the end of the Mammoth Event from less than zero to 8\% (standard definition) and again at the end of the Kaena transition. Similar shifts can also be seen at the Matuyama Gauss transition at about 2.58 Ma and at the Reunion Excursion - as well as a relatively rapid large positive shift at the Gilbert-Gauss Reversal. These rapid increases in $15 \mathrm{~N}$ could be due to a change in biological productivity from warmer waters (as indicated by the TEX derived SST) however, the surface waters are relatively shallow (ice is frequently grounded in the record) and so the recorded changes in sea-level may have affected affect these readings; certainly (their) Figure 2 shows longer ice durations for the period starting at about 3.3 $\mathrm{Ma}$ (from sea ice diatoms) and no relation exists between the high $15 \mathrm{~N}$ values and the icesheet extension (Glacial proximity) [79].

There is the possibility that these cooling events may have been subject to precessional forcing, which has been raised by Caballero-Gill et al (2020) [80], the authors make 
the case for a cooling frequency of $100 \mathrm{ka}$, although it can be seen in Valet et al (2020) [75] that periods of low geomagnetic intensity also align closely with periods of cooling.

Similar sharp spikes in $15 \mathrm{~N}$ can be seen at about 2.1 Ma 3.14 and 3.6 Ma in Ocean Drilling Program (ODP) Site 1012 (32N, 118W) in a non-glacial setting (Liu et al 2008) [81]: during the stable Mammoth chron, $15 \mathrm{~N}$ levels are less enriched levels when the intensity of the field is higher. The same sharp steps in $\mathrm{d} 15 \mathrm{~N}$ are seen in the African coast in boreholes from the Benguela current region: at $3 \mathrm{Ma}, 2.6 \mathrm{Ma}$ and in particular at 2.05 Ma for subtropical borehole 1082 (22S), and at 3Ma, 2.6 Ma and 2.05 Ma for the sub-Antarctic borehole 1090 (43S) (Etourneau et al 2009)[82]. Thus is possible that the apparent loss in atmosphere indicated by the paleo-Patm proxies (amber and $\mathrm{pCO}_{2}$ ) not only resulted in the global cooling seen in the record, but also led to a reduction in species size of teratorns and storks.

\subsubsection{Dynamic Soaring in Pelagornithids}

The wind profile over relatively calm sea is often expressed as a logarithmic equation, where the velocity at a certain height is a function of friction (or shear) velocity, which in turn is a function of the inverse square root of air density. Thus the wind profile at a higher air density equivalent to 1.2 bar would be vertically extended by a factor of $\sqrt{1} 1.2(\sim 1.1)$ or $10 \%$.

Dynamic soaring is used by extant sea birds for long migrations (such as the Manx shearwater, Puffinus puffinus) or in foraging (albatross). In practice, the larger birds fly in an ' $S$ ' pattern in order to gain energy from the wind gradient. Pennycuick (2008)[12] and Richardson et al. (2018) [83] note that a two-layer model of wind speed consisting of zero wind in the lower layer and a more uniform wind in the upper layer helps in estimating the increase of airspeed and kinetic energy when a bird crosses the wind-shear layer. The strong winds of Southern Ocean create a wind gradient which for a $10 \mathrm{~m} / \mathrm{s}$ wind (at standard height) the greatest wind speed differences are from the sea surface to about $10 \mathrm{~m}$ in height and thus where the energy harvested is greatest. This is confirmed by behavioural observations: the average flight height of Laysan (Phoebastria immutabilis) and wandering albatrosses was found to be between 3 to $8 \mathrm{~m}$ (Yonehara et al., 2016)[84], similar to the average flying height for albatross of $5 \mathrm{~m}$ observed off Bird Island (Pennycuick, 1982)[85] and the height range of highest energy gain between about 5 and $15 \mathrm{~m}$ found by Sachs et al. (2012)[86]. At the higher air density (1.2 bar) the extra 10\% would allow better energy harvesting from 5.5 to $16.5 \mathrm{~m}$ and with higher lift (proportional to rho), favoring a bird with longer wingspan and better aerodynamic penetration (heavier), which would allow faster foraging. A drop in air density would remove these advantages, as noted in Cannell (2020)[9] for the Giant Pelagornithidae species of the Eocene and Miocene, which became reduced in size. At 1 bar the optimum wingspan for dynamic soaring may have been reduced to a value similar to the largest extant albatross size (from 5.1 to $3 \mathrm{~m}$ or linear reduction of $59 \%$ ), which would reduce the mass of a pelagornithid to about $4.8 \mathrm{~kg}$ : a body plan possibly too light for aerodynamic penetration in strong winds. Thus unlike the teratorns and storks, downsizing may not have been an option for the Pelagornithidae.

\subsubsection{Takeoff and Landing Airspeeds}

Flight speed is expected to increase with mass and wing loading among birds (and aircraft) for fundamental aerodynamic reasons and Alerstam et al (2007)[67] tested this hypothesis with a database of multiple tracked flights for 138 bird species. The data showed that other constraints have an important influence on cruising flapping flight speed that go beyond aerodynamic scaling effects (such as phylogenetic group). However, when this data, together with level flapping cruising flight of other bird species (Pennycuick 1997)[87] is examined for large birds (mass $>1 \mathrm{~kg}$ ) another factor emerges: an overall limitation of flapping flying speed. Using a takeoff speed for all species of $70 \%$ of flapping cruise speed gives the relation shown in Figure 2. For nearly all birds above $\sim 4$ $\mathrm{kg}$, takeoff airspeed is limited to around 11 to $12 \mathrm{~m} / \mathrm{s}$. Body mass and wingspan were derived from a review of 33610 specimens and the radar tracking of the larger birds was 
largely for level flight or with a slight vertical component, and include swans, pelicans, eagles, geese, storks, flamingos, cranes, cormorants, ducks, spoonbills, gulls, vultures and ravens. Data on the Andean Condor (McGahan 1972) [65] has been added in red along with observational data of level flight of 17 large species by Pennycuick 1997.[87]

The data of Cygnus cygnus (blue) is based on only one tracked flight. The flight of the common crane (grus grus) is marked in green and differs in that this large bird has a low $\mathrm{AR}$ and long legs used to gain initial airspeed. However, data on the larger Antigone canadensis, (formerly Grus Canadensis) gives a flight speed of $12 \mathrm{~m} / \mathrm{s}$ (Tacha et al 1992)[88] whereas Flight 1.25 estimates a minimum power speed of $15.5 \mathrm{~m} / \mathrm{s}(6 \mathrm{~kg}$, wingspan $2.4 \mathrm{~m}$ and AR of 4); takeoff airspeed is thus possibly lower than $11 \mathrm{~m} / \mathrm{s}$.

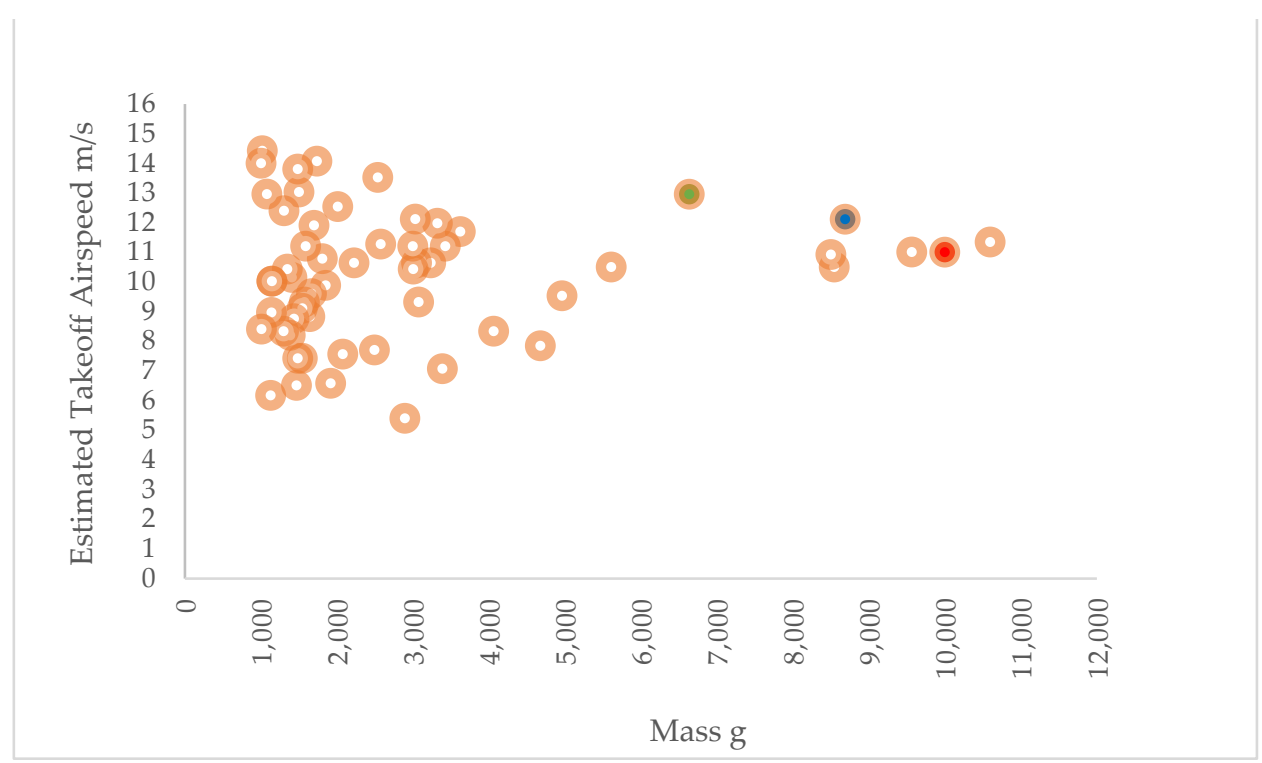

Figure 2. Takeoff Airspeeds (70\% Flapping Cruising speed) for Birds $>1 \mathrm{~kg}$ (From the data in Supplementary Notes Alerstam et al 2007[67] Pennycuick 1997 [87] and McGahan 1972) [65]

Alerstam et al (2007)[67] note that functional flight adaptations and constraints have an important influence on cruising flapping flight speed and takeoff airspeed appears to be one of these constraints and a limiting factor in determining maximum volant bird size and aerodynamics. This suggests that very large extinct birds of the Cenozoic may have had a flight medium that allowed takeoff speed to be also kept within the same constraint, i.e. a higher density as proposed by Pennycuick. At the predicted air density for the Pliocene of about the equivalent of $1.2 \mathrm{bar}$, takeoff airspeeds in relation to the present lowland and sea level of about 1 bar are shown in Table 1. Although this difference appears small, in terms of impact energy (proportional to airspeed squared), this represents a reduction of almost $20 \%$ in impact energy possibly of vital importance to a $20 \mathrm{~kg}$ bird with lightweight bones.

Table 1. Estimated Takeoff Airspeeds for Large Pliocene Birds at Present and Predicted Paleo Air Densities

\begin{tabular}{lccc}
\hline Air Density & \multicolumn{3}{c}{ Estimated Takeoff Airspeed $\mathbf{~ m} / \mathbf{s}$} \\
Equivalent & T. incredibelis & P. mauretanicus & Leptoptilos falconeri \\
\hline 1 bar & 13,2 & 11,3 & 13,23 \\
1.2 bar & 11,97 & 10,7 & 12,04 \\
\hline
\end{tabular}

Landing is also a risk for large birds and is normally preceded by a slow glide with a high angle of attack to modify the wing profile (as in a flap). Simulations for all three large birds give a minimum sink glide speed of about $11 \mathrm{~m} / \mathrm{s}$ at 1 bar. At 1.2 bar this drops to 
about $8 \mathrm{~m} / \mathrm{s}$, and with a flap-like wing profile drag coefficient of 0.1 and increased lift coefficient of 3, airspeed drops to about $7 \mathrm{~m} / \mathrm{s}$, similar to the large extant birds presented in Flight 1.25 such as Gyps rueppellii $(7.3 \mathrm{~m} / \mathrm{s}$ with lift coefficient of 3 and wing profile coefficient of 0.1 ). For very large and heavy birds, landing in a higher density air would also be safer.

In order to test the kinetic energy methodology of a standing jump launch, simulations were carried out for the even larger Miocene saddlebill stork Ephippiorhynchus tchoufour with a linear dimensions of the tars metatarsus about 50\% larger than extant species, suggesting this bird may have stood at $2.20 \mathrm{~m}$ in height (Louchart et al 2008)[10]. Based on data from extant species this implies a wingspan of $4 \mathrm{~m}$, AR of 9 and mass of up to $25 \mathrm{~kg}$ for a male; or with a full crop, a takeoff mass of about $28 \mathrm{~kg}$. Flapping cruising speed at $1 \mathrm{bar}$ is $19.9 \mathrm{~m} / \mathrm{s}$, or a simulated takeoff airspeed of $13.93 \mathrm{~m} / \mathrm{s}$. This gives a kinetic energy of $2717 \mathrm{~J}$. With a muscle mass of $4.25 \mathrm{~kg}$, available burst power would be about $1700 \mathrm{~W}$ plus launch energy of around $130 \mathrm{~J}$ : a ratio of power to energy of 0.66 . The bird would be extremely underpowered for a jump takeoff. At 1.4 bar, airspeed is $11.9 \mathrm{~m} / \mathrm{s}$ kinetic energy is further reduced and the power to energy ratio is about 1. A jump takeoff therefore becomes viable at about level of air density suggested by Cannell (2020)[9] for the Giant Teratorn and Pelagornithid species according to simulations with Flight 1.25, with all three giant Miocene species having estimated takeoff speeds of between 11 and $13 \mathrm{~m} / \mathrm{s}$ in agreement with the apparent limit for large extant birds.

\subsubsection{Other possible impacts of atmospheric loss}

According to Chemke \& Kapsi (2017)[89], a more massive atmosphere on an earth like planet would cause adiabatic warming, changes in Hadley Cells and reduce the temperature gradient from the equator to the poles. Thus if atmospheric loss affected the flight of all large birds, these climate impacts should have resulted in a cooler world with a higher temperature gradient after $\sim 3 \mathrm{Ma}$. This is seen in the record: Ballantyne et al (2010) [90] note that during the Pliocene warm period the Arctic was $19{ }^{\circ} \mathrm{C}$ warmer than today, whereas Antarctica was only $\sim 13{ }^{\circ} \mathrm{C}$ warmer (based on three independent proxies from an early Pliocene peat deposit in the Canadian High Arctic), although tropical sea surface temperatures (SST) were similar to the present. This distribution has long been a puzzle and Fedorov et al (2003)[91] found that the mechanisms currently proposed in an Earth system model could not explain Pliocene warmth and simultaneously reproduce these features. More recently, Haywood et al (2016) [92] note in a review of geological archives and climate models that although high-latitude SST reconstructions indicate substantial warming, the lack of tropical SST warming in areas outside upwelling zones has proven puzzling: along with the paradox that a reduced latitudinal SST gradient implies potentially weaker atmospheric forcing of oceanic circulation, and hence weaker oceanic heat transport.

\section{Conclusions}

Three species of very large birds with habitats that ranged from temperate to subtropical, coastal, mountain and savannah and covering the Americas, Eurasia, Africa and Antarctica disappeared from the fossil record at about $3 \mathrm{Ma}$, which strongly suggests a global phenomenon. After flourishing for more than 50 Ma the Pelagornithidae, became extinct, although other smaller species of teratorns and storks continued to exist up to the Holocene. Thus the factor that links the extinct species to this critical period is their extreme size and mass.

The very low magnetic fields encountered in the Mammoth and Kaena Reversals exposed the atmosphere to solar winds and other events atmosphere allowing for the potential loss of lighter volatiles. Two proxies of paleo Patm derived from amber (resin) and the difference between $\mathrm{pCO}_{2}$ as derived from global marine and terrestrial sources indicate a drop in paleo-Patm from about 1.2 to 1 bar over the period $3 \mathrm{Ma}$ to 2.6 Ma BP. 
Maximum bird size may be limited by available power, and Pennycuick (2008) indicates that this maximum all-up mass of birds that are able to fly horizontally would be around $16 \mathrm{~kg}$. Another limit is the energy required for takeoff - either by jumping (in which Borelli's Rule limits launch speed) or from other airspeed constraints which limit takeoff speed for all large extant birds at around 11 to $12 \mathrm{~m} / \mathrm{s}$ and are possibly related to risk of injury. These constraints, including available power, are dependent on the flight medium density and at 1 bar, the stork and teratorn with mass of $20 \mathrm{~kg}$ or more have estimated takeoff airspeeds higher than the extant critical level of 11 to $12 \mathrm{~m} / \mathrm{s}$. At the proxy level of 1.2 bar for the Pliocene of the period before $3 \mathrm{Ma}$, all airspeed values are within this limit and a standing jump takeoff would have been also been within the energy constraint of the large stork.

Any changes in atmospheric mass would have had impacted the climate, causing cooling and a greater temperature gradient from the equator to the poles. This is in agreement with the geological record.

Supplementary Materials: The following are available online at www.mdpi.com/xxx/s1, Figure S1: title, Table S1: title, Video S1: title. (as per the review and edit)

Funding: This research received no external funding.

Conflicts of Interest: The author declares no conflict of interest.

\section{References}

1. Campbell Jr., K.E. and Marcus, L. (1992) The relationships of hindlimb bone dimensions to body weight in birds. Natural History Museum of Los Angeles County Science Series, 36, 395-412.

2. Campbell KE Jr.1995. Additional specimens of the Giant Teratorn,Argentavis magnificens, from Argentina (Aves: Teratornithidaei).Cour Forsch Senck. 181:199-201.

3. Palmqvist P, Vizcaíno SF.2003. Ecological and reproductive constraints ofbody size in the giganticArgentavis magnificens(Aves, Teratornithidae)from the Miocene of Argentina. Ameghiniana. 40:379-385.

4. Ksepka D T Flight performance of the largest volant bird. Proceedings of the National Academy of Sciences Jul 2014, 111 (29) 10624-10629; DOI: 10.1073/pnas.1320297111

5. Mayr, Gerald and David Rubilar. (2010). Osteology of a new giant bony-toothed bird from the Miocene of Chile, with a revision of the taxonomy of Neogene Pelagornithidae. Journal of Vertebrate Paleontology, Volume 30, No. 5.

6. Cenizo, M., Hospitaleche, C.A., \& Reguero, M. (2015). Diversity of pseudo-toothed birds (Pelagornithidae) from the Eocene of Antarctica. Journal of Paleontology, 89, 870 - 881.

7. Kloess P A, Poust A W and Stidham T A (2020) Earliest fossils of giant-sized bony-toothed birds (Aves: Pelagornithidae) from the Eocene of Seymour Island, Antarctica. Scientific Reports. DOI: 10.1038/s41598-020-75248-6

8. Field, D.J., Lynner, C., Brown, C. \& Darroch, S.A.F. (2013) Skeletal correlates for body mass estimation in modern and fossil flying birds. PLoS ONE, 8, e82000. DOI:10.1371/journal.pone.0082000.

9. Cannell AER (2020) Too big to fly? An engineering evaluation of the fossil biology of the giant birds of the Miocene in relation to their flight limitations, constraining the minimum air pressure at about 1.3 bar. Animal Biology 70(3):1-20 DOI: 10.1163/15707563-bja10001

10. Louchart, A., Y. Haile-Selassie, P. Vignaud, A. Likius and M. Brunet (2008). "Fossil birds from the Late Miocene of Chad and Ethiopia and zoogeographical implications." Oryctos 7: 147-167

11. Elliott, A., E. F. J. Garcia, and P. F. D. Boesman (2020). Marabou Stork (Leptoptilos crumenifer), version 1.0. In Birds of the World (J. del Hoyo, A. Elliott, J. Sargatal, D. A. Christie, and E. de Juana, Editors). Cornell Lab of Ornithology, Ithaca, NY, USA. https://doi.org/10.2173/bow.marsto1.01

12. Pennycuick, C.J. (2008) Modelling the Flying Bird. Academic Press, Burlington, MA, USA.

13. Xiang, Z., Ni, B., Zhou, C., Zou, Z., Gu, X., Zhao, Z., Zhang, X., Zhang, X., Zhang, S., Li, X., Zuo, P., Spence, H., and Reeves, G.: Multi-satellite simultaneous observations of magnetopause and atmospheric losses of radiation belt electrons during an intense solar wind dynamic pressure pulse, Ann. Geophys., 34, 493-509, https://doi.org/10.5194/angeo-34-493-2016, 2016.

14. Wei, Y., Pu, Z., Zong, Q., Wan, W., Ren, Z., Fraenz, M., Dubinin, E., Tian, F., Shi, Q., Fu, S., \& Hong, M. (2014). Oxygen escape from the Earth during geomagnetic reversals: Implications to mass extinction. Earth and Planetary Science Letters, 394, 94-98.

15. Schillings, A., Slapak, R., Nilsson, H., Yamauchi, M., Dandouras, I., \& Westerberg, L. (2019). Earth atmospheric loss through the plasma mantle and its dependence on solar wind parameters. Earth, Planets and Space, 71, 1-13.

16. Wong, M. H., et al. (2013), Isotopes of nitrogen on Mars: Atmospheric measurements by Curiosity's mass spectrometer, Geophys. Res. Lett., 40, 6033- 6037, doi:10.1002/2013GL057840. Louchart, A., Vignaud, P., Likius, A., Brunet, M., \& White, T.D. (2005). A large extinct marabou stork in African Pliocene hominid sites, and a review of the fossil species of Leptoptilos. 
17. Stolper DA, Bender ML, Dreyfus GB, Yan Y, Higgins JA. A Pleistocene ice core record of atmospheric O2 concentrations. Science. 2016 Sep 23;353(6306):1427-1430. doi: 10.1126/science.aaf5445. PMID: 27708037.

18. Rimmer PB, Shorttle O, Rugheimer S. Oxidised micrometeorites as evidence for low atmospheric pressure on the early Earth. Geochem Perspect Lett. 2019;9:38-42. doi: 10.7185/geochemlet.1903. Epub 2019 Feb 11. PMID: 31187073; PMCID: PMC6558283.

19. Johnson, B. W., \& Goldblatt, C. (2018). EarthN: A new earth system nitrogen mode. Geochemistry, Geophysics, Geosystems, 19, 2516- 2542. https://doi.org/10.1029/2017GC007392

20. Campbell, K.E., \& Tonni, E.P. (1983). Size And Locomotion In Teratorns (Aves: Teratornithidae). The Auk, 100, $390-403$.

21. Campbell, K. E., Jr., E. Scott, \& K. B. Springer. 1999. A new genus for the incredible teratorn (Aves: Teratornithidae). Smithsonian Contributions to Paleobiology, 89:169-175.

22. Mourer-Chauviré, C., \& Geraads, D. (2005). The Struthionidae and Pelagornithidae (Aves: Struthioniformes, Odontopterygiformes) from the late Pliocene of Ahl al Oughlam, Morocco.

23. Louchart, A., Sire, J. Y., Mourer-Chauviré, C., Geraads, D., Viriot, L., \& de Buffrénil, V. (2013). Structure and growth pattern of pseudoteeth in Pelagornis mauretanicus (Aves, Odontopterygiformes, Pelagornithidae). PloS one, 8(11), e80372. https://doi.org/10.1371/journal.pone.0080372

24. Cécile Mourer-Chauviré, Denis Geraads. The Upper Pliocene Avifauna of Ahl al Oughlam, Morocco. Systematics and Biogeog-

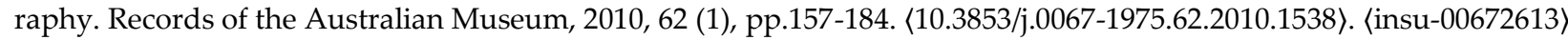

25. Boessenecker, R., \& Smith, N.A. (2011). Latest Pacific Basin Record of a Bony-Toothed Bird (Aves, Pelagornithidae) from the Pliocene Purisima Formation of California, U.S.A.

26. Powell, C.L., II, Barron, J.A., Sarna-Wojcicki, A.M., Clark, J.C., Perry, F.A., Brabb, E.E., and Fleck, R.J. 2007. Age, stratigraphy, and correlation of the late Neogene Purisima Formation, central California coast ranges. US Geological Survey Professional Paper 1740: 1-32

27. Chavéz, M., M. Stucchi, and M. Urbina. 2007. El registro de Pelagornithidae (Aves: Pelecaniformes) y la avifauna neogena del Pacífico sudeste. Bulletin de l'Institut Français d'Etudes Andines 36:175-197.

28. Ono, K. 1989. A bony-toothed bird from the Middle Miocene, Chichibu Basin, Japan. Bulletin of the National Science Museum, Tokyo, Series C 15:33-38.

29. Louchart, A., Vignaud, P., Likius, A., Brunet, M., \& White, T. (2005). A large extinct marabou stork in African Pliocene hominid sites, and a review of the fossil species of Leptoptilos. Acta Palaeontologica Polonica, 50, 549-563.

30. Nudds RL, Bryant DM. Consequences of load carrying by birds during short flights are found to be behavioral and not energetic. Am J Physiol Regul Integr Comp Physiol. 2002; 283 (1) :R249-R256. doi:10.1152/ajpregu.00409.2001

31. Askew GN, Marsh RL, Ellington CP. The mechanical power output of the flight muscles of blue-breasted quail (Coturnix chinensis) during take-off. J Exp Biol. 2001;204(Pt 21):3601-3619.

32. Earls, K.D. (2000). Kinematics and mechanics of ground take-off in the starling Sturnis vulgaris and the quail Coturnix coturnix. The Journal of experimental biology, 203 Pt 4, 725-39.

33. Provini, P., Tobalske, B.W., Crandell, K.E., \& Abourachid, A. (2014). Transition from wing to leg forces during landing in birds. Journal of Experimental Biology, 217, 2659 - 2666.

34. Bobbert M. F. (2013). Effects of isometric scaling on vertical jumping performance. PloS one, 8(8), e71209. https://doi.org/10.1371/journal.pone.0071209

35. Seyfullah LJ, Beimforde C, Dal Corso J, Perrichot V, Rikkinen J, Schmidt AR. Production and preservation of resins - past and present. Biol Rev Camb Philos Soc. 2018;93(3):1684-1714. doi:10.1111/brv.12414

36. Takeishi H, Hayashi J, Okazawa A, Harada K, Hirata K, Kobayashi A, Akamatsu F. Effects of elevated pressure on rate of photosynthesis during plant growth. J Biotechnol. 2013 Oct 20;168(2):135-41. doi: 10.1016/j.jbiotec.2013.08.012. Epub 2013 Aug 29. PMID: 23994480

37. Kellner A WA (2015). Comments on Triassic pterosaurs with discussion about ontogeny and description of new taxa. Anais da Academia Brasileira de Ciências 87(2): (Annals of the Brazilian Academy of Sciences). 669-689. http://dx.doi.org/10.1590/00013765201520150307

38. Xu, G. H., Zhao, L. J., Gao, K. Q., \& Wu, F. X. (2013). A new stem-neopterygian fish from the Middle Triassic of China shows the earliest over-water gliding strategy of the vertebrates. Proceedings. Biological sciences, 280(1750), 20122261.

39. https://doi.org/10.1098/rspb.2012.2261

40. Simmons NB. Evolution. An Eocene big bang for bats. Science. 2005;307(5709):527-528. doi:10.1126/science.1108871

41. Tappert, R., McKellar, R.C., Wolfe, A., Tappert, M.C., Ortega-Blanco, J., \& Muehlenbachs, K. (2013). Stable carbon isotopes of C3 plant resins and ambers record changes in atmospheric oxygen since the Triassic. Geochimica et Cosmochimica Acta, 121, 240-262.

42. Nissenbaum A and Yakir D. Stable Isotope Composition of Amber. In: Amber, Resinite, and Fossil Resins, Chapter 2pp 32-42. DOI: 10.1021/bk-1995-0617.ch002. American Chemical Society, SeriesVol. 617. ISBN13: 9780841233362eISBN: 9780841215535

43. McKellar, R.C., Chatterton, B., Wolfe, A., \& Currie, P.J. (2011). A Diverse Assemblage of Late Cretaceous Dinosaur and Bird Feathers from Canadian Amber. Science, 333, 1619 - 1622.

44. Kocsis, L., Usman, A., Jourdan, A., Hassan, S.H., Jumat, N., Daud, D., Briguglio, A., Slik, F., Rinyu, L., \& Futó, I. (2020). The Bruneian record of "Borneo Amber": A regional review of fossil tree resins in the Indo-Australian Archipelago. Earth-Science Reviews, 201, 103005.

45. Berner RA, Petsch ST, Lake JA, Beerling DJ, Popp BN, Lane RS, Laws EA, Westley MB, Cassar N, Woodward FI, Quick WP. Isotope fractionation and atmospheric oxygen: implications for phanerozoic O(2) evolution. Science. 2000 Mar 3;287(5458):16303. doi: 10.1126/science.287.5458.1630. PMID: 10698733. 
46. Beerling, D., \& Royer, D. (2002). Fossil Plants as Indicators of the Phanerozoic Global Carbon Cycle. Annual Review of Earth and Planetary Sciences, 30, 527-556.

47. Belcher CM, Yearsley JM, Hadden RM, McElwain JC, Rein G. Baseline intrinsic flammability of Earth's ecosystems estimated from paleoatmospheric oxygen over the past 350 million years. Proc Natl Acad Sci U S A. 2010 Dec 28;107(52):22448-53. doi: 10.1073/pnas.1011974107. Epub 2010 Dec 13. PMID: 21149686; PMCID: PMC3012516.

48. Wilmshurst P. (1998). Diving and oxygen. BMJ (Clinical research ed.), 317(7164), 996-999. https://doi.org/10.1136/bmj.317.7164.996

49. Berner, R. (2006). GEOCARBSULF: A combined model for Phanerozoic atmospheric O2 and CO2. Geochimica et Cosmochimica Acta, 70, 5653-5664.

50. Royer, D., Donnadieu, Y., Park, J., Kowalczyk, J.B., \& Goddéris, Y. (2014). Error analysis of CO2 and O2 estimates from the longterm geochemical model GEOCARBSULF. American Journal of Science, 314, 1259 - 1283.

51. Rae, J.B., Foster, G., Schmidt, D., \& Elliott, T. (2011). Boron isotopes and B/Ca in benthic foraminifera: proxies for the deep ocean carbonate system. Earth and Planetary Science Letters, 302, 403-413.

52. Rae, J.W.B., A. Burke, L.F. Robinson, J.F. Adkins, T. Chen, C. Cole, R. Greenop, T. Li, E.F.M. Littley, D.C. Nita, and others. 2018. CO2 storage and release in the deep Southern Ocean on millennial to centennial timescales. Nature 562:569-573, https://doi.org/10.1038/s41586-018-0614-0.

53. O'Brien CL, Huber M, Thomas E, Pagani M, Super JR, Elder LE, Hull PM. The enigma of Oligocene climate and global surface temperature evolution. Proc Natl Acad Sci U S A. 2020 Oct 13;117(41):25302-25309. doi: 10.1073/pnas.2003914117. Epub 2020 Sep 28. PMID: 32989142; PMCID: PMC7568263.

54. Bailey, N.J., Papakyriakou, T., Bartels, C., \& Wang, F. (2018). Henry's Law constant for CO2 in aqueous sodium chloride solutions at $1 \mathrm{~atm}$ and sub-zero (Celsius) temperatures. Marine Chemistry, 207, 26-32.

55. Al-Anezi K., Somerfield C., Mee D. and Hilal N., "Parameters Affecting the Solubility of Carbon Dioxide in Seawater at the Conditions Encountered in MSF Desalination Plants," Desalination, Vol. 222, No. 1-3, 2008, pp. 548-571. doi:10.1016/j.desal.2007.01.128

56. de la Vega, E., Chalk, T. B., Wilson, P. A., Bysani, R. P., \& Foster, G. L. (2020). Atmospheric CO2 during the Mid-Piacenzian Warm Period and the M2 glaciation. Scientific reports, 10(1), 11002. https://doi.org/10.1038/s41598-020-67154-8

57. Sosdian, S. M., Greenop, R., Hain, M. P., Foster, G. L., Pearson, P. N., and Lear, C. H, (2018).: Constraining the evolution of Neogene ocean carbonate chemistry using the boron isotope pH proxy, Earth Planet. Sc. Lett., 498, 362-376, https://doi.org/10.1016/J.EPSL.2018.06.017

58. Bartoli, G., Hönisch, B., and Zeebe, R. E. (2011). Atmospheric CO2 decline during the Pliocene intensification of Northern Hemisphere glaciations, Paleoceanography, 26, PA4213,https://doi.org/10.1029/2010PA002055,

59. Badger, M; Chalk, T B; Foster, G L; Bown, P R; Gibbs, S J; Sexton, P; Schmidt, D N; Pälike, H; Mackensen, A and Pancost, R D (2019). Insensitivity of alkenone carbon isotopes to atmospheric CO2 at low to moderate CO2 levels. Climate of the Past, 15 pp. 539-554. DOI: https://doi.org/10.5194/cp-15-539-2019

60. Martínez-Botí MA, Foster GL, Chalk TB, Rohling EJ, Sexton PF, Lunt DJ, Pancost RD, Badger MP, Schmidt DN. Plio-Pleistocene climate sensitivity evaluated using high-resolution CO2 records. Nature. 2015 Feb 5;518(7537):49-54. doi: 10.1038/nature14145. Erratum in: Nature. 2015 Oct 15;526(7573):458. PMID: 25652996.

61. Stap, L.B., Boer, B.D., Ziegler, M., Bintanja, R., Lourens, L., \& Wal, R.V. (2016). CO2 over the past 5 million years : Continuous simulation and new $\delta 11 B$-based proxy data. Earth and Planetary Science Letters, 439, 1-10.

62. Wang Y, Momohara A, Wang L, Lebreton-Anberrée J, Zhou Z (2015) Evolutionary History of Atmospheric CO2 during the Late Cenozoic from Fossilized Metasequoia Needles. PLoS ONE 10(7): e0130941. https://doi.org/10.1371/journal.pone.0130941

63. Fletcher, T.L., Warden, L., Damsté, J.S., Brown, K.J., Rybczynski, N., Gosse, J., \& Ballantyne, A. (2019). Evidence for fire in the Pliocene Arctic in response to amplified temperature. Climate of The Past, 15, 1063-1081.

64. Cui, Y., Schubert, B.A., and Jahren, A.H., 2020, A 23 m.y. record of low atmospheric CO2: Geology, v. 48, p. XXX-XXX, https://doi.org/10.1130/G47681.1

65. McGahan J. Flapping flight of the Andean condor in nature. J Exp Biol. 1973;58(1):239-253.

66. Williams H. J., Shepard E. L. C., Holton M D., Alarcón P. A. E., Wilson R. P., Lambertucci S. A.. (2020). Physical limits of flight performance in the heaviest soaring bird. Proceedings of the National Academy of Sciences Jul, 117 (30) 17884-17890; DOI: 10.1073/pnas.1907360117

67. Alerstam, T., Rosén, M., Bäckman, J., Ericson, P. G., \& Hellgren, O. (2007). Flight speeds among bird species: allometric and phylogenetic effects. PLoS biology, 5(8), e197. https://doi.org/10.1371/journal.pbio.0050197

68. Pimiento, C., Griffin, J.N., Clements, C.F. et al. The Pliocene marine megafauna extinction and its impact on functional diversity. Nat Ecol Evol 1, 1100-1106 (2017). https://doi.org/10.1038/s41559-017-0223-6

69. Chávez Hoffmeister M, Carrillo Briceño JD, Nielsen SN (2014) The Evolution of Seabirds in the Humboldt Current: New Clues from the Pliocene of Central Chile. PLoS ONE 9(3): e90043. doi:10.1371/journal.pone.0090043

70. Melott AL, Marinho F, Paulucci L. Hypothesis: Muon Radiation Dose and Marine Megafaunal Extinction at the End-Pliocene Supernova. Astrobiology. 2019;19(6):825-830. doi:10.1089/ast.2018.1902

71. Marshall JEA, Lakin J, Troth I, Wallace-Johnson SM. UV-B radiation was the Devonian-Carboniferous boundary terrestrial extinction kill mechanism. Sci Adv. 2020;6(22):eaba0768. Published 2020 May 27. doi:10.1126/sciadv.aba0768

72. Benca JP, Duijnstee IAP, Looy CV. UV-B-induced forest sterility: Implications of ozone shield failure in Earth's largest extinction. Sci Adv. 2018;4(2):e1700618. Published 2018 Feb 7. doi:10.1126/sciadv.1700618 
73. Foster C.B. and Afonin S.A. Abnormal pollen grains: an outcome of deteriorating atmospheric conditions around the PermianTriassic boundary. Journal of the Geological Society, 162, 653-659, 1 July 2005, https://doi.org/10.1144/0016-764904-047

74. Sullivan, T. N., Meyers, M. A., \& Arzt, E. (2019). Scaling of bird wings and feathers for efficient flight. Science advances, 5(1), eaat4269. https://doi.org/10.1126/sciadv.aat4269

75. Valet, Jean-Pierre; Thevarasan, Anojh; Bassinot, Franck; Savranskaia, Tatiana; Haddam, Naoufel (2020): Two Records of Relative Paleointensity for the Past 4 Myr. Frontiers. Collection. https://doi.org/10.3389/feart.2020.00148

76. Emilio Herrero-Bervera \& Jean-Pierre Valet. (2005) Absolute paleointensity and reversal records from the Waianae sequence (Oahu, Hawaii, USA). Earth and Planetary Science Letters 234(1-2):279-296 DOI: 10.1016/j.epsl.2005.02032

77. Valet, J. P., \& Fournier, A. (2016). Deciphering records of geomagnetic reversals. Reviews of geophysics (1985), 54(2), 410-446. https://doi.org/10.1002/2015RG000506

78. Goguitchaichvili, A., Cervantes, M., Rathert, M.C., Camps, P., Sologashvili, J., \& Maissuradze, G. (2009). Gilbert-Gauss geomagnetic reversal recorded in Pliocene volcanic sequences from Georgia (Lesser Caucasus): revisited. Earth, Planets and Space, 61, 71-81.

79. Robert McKay, Tim Naish, Lionel Carter, Christina Riesselman, Robert Dunbar, Charlotte Sjunneskog, Diane Winter, Francesca Sangiorgi, Courtney Warren, Mark Pagani, Stefan Schouten, Veronica Willmott, Richard Levy, Robert DeConto, Ross D. Powell Antarctic influences on Late Pliocene cooling. Proceedings of the National Academy of Sciences Apr 2012, 109 (17) 6423-6428; DOI: 10.1073/pnas.1112248109

80. Caballero-Gill, R. P., Herbert, T. D., \& Dowsett, H. J. (2019). 100-kyr paced climate change in the Pliocene warm period, Southwest Pacific. Paleoceanography and Paleoclimatology, 34, 524-545. https://doi.org/10.1029/2018PA003496

81. Liu, Z., M. A. Altabet, and T. D. Herbert (2008), Plio-Pleistocene denitrification in the eastern tropical North Pacific: Intensification at 2.1 Ma, Geochem. Geophys. Geosyst., 9, Q11006, doi:10.1029/2008GC002044

82. Etourneau, J., Martínez, P., Blanz, T., \& Schneider, R.R. (2009). Pliocene-Pleistocene variability of upwelling activity, productivity, and nutrient cycling in the Benguela region. Geology, 37, 871-874.

83. Richardson, P.L., Wakefield, E.D. \& Phillips, R.A. Flight speed and performance of the wandering albatross with respect to wind. Mov Ecol 6, 3 (2018). https://doi.org/10.1186/s40462-018-0121-9

84. Yonehara, Y., Goto, Y., Yoda, K., Watanuki, Y., Young, L.C., Weimerskirch, H., Bost, C.-A. \& Sato, K. (2016) Flight paths of seabirds soaring over the ocean surface enable measurement of fine-scale wind speed and direction. Proc. Natl Acad. Sci. USA, 113, 9039-9044.

85. Pennycuick, C.J. (1982) The flight of petrels and albatrosses (procellariiformes). observed in south Georgia and its vicinity. Phil. Trans. R. Soc. Lond. B Biol. Sci., 300, 75-106.

86. Sato, K., Sakamoto, K.Q., Watanuki, Y., Takahashi, A., Katsumata, N., Bost, C.-A. \& Weimerskirch, H. (2009) Scaling of soaring seabirds and implications for flight abilities of giant pterosaurs. PLoS ONE, 4, e5400. DOI:10.1371/journal.pone.0005400.

87. Pennycuick C. Actual and 'optimum' flight speeds: field data reassessed. J Exp Biol. 1997;200(Pt 17):2355-61. PMID: 9320274

88. Tacha, T.C., Nesbitt, S.A., and Vohs, P.A., 1992, Sandhill crane (Grus canadensis), in Poole, A., ed., The birds of North America. Ithaca, New York, Cornell Lab of Ornithology, 24 p.

89. Chemke R and Kaspi Y. Dynamics of Massive Atmospheres (2017). The Astrophysical Journal, Volume 845, Number 1

90. Ballantyne A. P. et al.. Significantly warmer Arctic surface temperatures during the Pliocene indicated by multiple independent proxies. Geology 38, 603-606 (2010).

91. Fedorov AV, Brierley CM, Lawrence KT, Liu Z, Dekens PS, Ravelo AC. Patterns and mechanisms of early Pliocene warmth. Nature. 2013 Apr 4;496(7443):43-9. doi: 10.1038/nature12003. PMID: 23552943.

92. Haywood, A. M., Dowsett, H. J., \& Dolan, A. M. (2016). Integrating geological archives and climate models for the mid-Pliocene warm period. Nature communications, 7, 10646. https://doi.org/10.1038/ncomms10646 